ETNIK : Jurnal Ekonomi - Teknik

ISSN: 2808-6694 (Online);2808-7291 (Print)

Jurnal Homepage https://etnik.rifainstitute.com

\title{
ANALISIS EKUITAS MEREK AQUA BERDASARKAN PERSEPSI KUALITAS MEREK (BRAND PERCEIVED QUALITY) PADA PENGGUNA MEDIA SOSIAL INSTAGRAM
}

\author{
Chanissa Purwaningrum, Tiara Adhelya Putri, Tania Saulina
}

Universitas Bina Sarana Informatika Jakarta

\section{Informasi Artikel}

Histori Artikel:

Diterima

07 Desember 2021

Direvisi

15 Desember 2021

Diterbitkan

20 Desember 2021

\section{Email Author:}

Channisa.csp@bsi.ac.id

\begin{abstract}
PT AQUA Golden Mississippi, Tbk is one of the many brands that produce mineral water with various packaging needed. AQUA as the market leader in the bottled water product category, has a strong brand equity. In addition, AQUA increases the perceived quality in the eyes of consumers by adding a variety of choices of bottled drinking water of various sizes. In general, the purpose of this study is to get an overview of AQUA's brand equity, while in more detail the purpose of this study is to analyze the perception of brand quality in drinking water in the AQUA brand packaging among the social media users of Instagram. This research is a type of survey research, where the research aims to find out about the measurement of brand equity based on brand perceived quality elements in AQUA brand beverage products. The number of samples in this study were 374 samples, namely 365 women and 9 men. Based on the results of the study, it can be concluded from the percentage of $97.9 \%$ who chose strongly agree and agree, that respondents believe in the quality given that AQUA has clear water in the eyes of consumers, $93.3 \%$ who voted strongly agree and agree, that the bottled water produced by the AQUA brand does not have a smell or smell in the eyes of consumers, $68.2 \%$ of AQUA consumers choose strongly agree and agree it is proven that the quality of AQUA is very good, $90.7 \%$ who choose strongly agree and agree, that AQUA is believed to be a hygienic product in the eyes of consumers, $96 \%$ who voted strongly agree and agree, that AQUA can make it easier to consume drinking water in the eyes of consumers, $96.3 \%$ who choose strongly agree and agree, that AQUA has an easy logo recognized and remembered in the eyes of consumers, $96.3 \%$ who voted strongly agree and agree, that AQUA has good packaging in the eyes of consumers, $79 \%$ who chose strongly agree and agree, that AQUA has the same quality from time to time in the eyes of consumers, $89,3 \%$ who voted strongly agree and agree that AQUA has a price that is in accordance with the volume/size in the eyes of consumers
\end{abstract}

Keyword- Equity Analysis, AQUA, Brand 


\begin{abstract}
ABSTRAK
PT AQUA Golden Mississippi, Tbk merupakan salah satu dari sekian banyak merek yang memproduksi air mineral dengan berbagai kemasan yang dibutuhkan. AQUA sebagai market leader dikategori produk air minum dalam kemasan, telah memiliki brand equity yang kuat. Selain itu, AQUA meningkatkan perceived quality dimata konsumen dengan menambah varian pilihan air minum dalam kemasan dengan berbagai ukuran. Secara umum tujuan penelitian ini untuk mendapatkan gambaran tentang ekuitas merek AQUA, adapun untuk lebih rincinya tujuan penelitian ini adalah untuk menganalisis persepsi kualitas merek pada air minum dalam kemasan merek AQUA di kalangan masyarakat pengguna media sosial Instagram. Penelitian ini merupakan jenis penelitian survei, yang dimana penelitian bertujuan untuk mencari tahu mengenai pengukuran ekuitas merek berdasarkan elemen brand perceived quality pada produk minuman merek AQUA, Jumlah sampel dalam penelitian ini ada 374 Sampel yaitu sebanyak 365 perempuan dan 9 laki-laki. Berdasarkan hasil penelitian, dapat disimpulkan dari persentase sebesar 97,9\% yang memilih sangat setuju dan setuju, bahwa responden percaya dengan kualitas yang diberikan bahwa AQUA memiliki air yang jernih dimata konsumen, 93,3\% yang memilih sangat setuju dan setuju, bahwa AMDK yang diproduksi merek AQUA tidak memiliki aroma atau bau dimata konsumen, $68.2 \%$ konsumen AQUA memilih sangat setuju dan setuju terbukti bahwa kualitas dari AQUA sangat bagus, 90,7\% yang memilih sangat setuju dan setuju, bahwa AQUA dipercaya merupakan produk yang higienis dimata konsumen, $96 \%$ yang memilih sangat setuju dan setuju, bahwa AQUA dapat memudahkan dalam mengosumsi air minum dimata konsumen, 96,3\% yang memilih sangat setuju dan setuju, bahwa AQUA memiliki logo yang mudah dikenali dan diingat dimata konsumen, 96,3\% yang memilih sangat setuju dan setuju, bahwa AQUA memiliki kemasan yang bagus dimata konsumen, 79\% yang memilih sangat setuju dan setuju, bahwa AQUA memiliki kualitas yang sama dari waktu ke waktu dimata konsumen, 89,3\% yang memilih sangat setuju dan setuju, bahwa AQUA memiliki harga yang sesuai dengan volume/ukuran dimata konsumen.
\end{abstract}

Kata Kunci -Analisis Ekuitas, AQUA, Merek

\title{
PENDAHULUAN
}

Salah satu aset yang digunakan perusahaan untuk memasarkan produknya dan tetap dapat bersaing dan meraup pangsa pasar adalah merek (Brand) (Sudarwati and Eka Satya 2013). Merek 
telah menjadi elemen krusial yang berkontribusi terhadap kesuksesan sebuah organisasi pemasaran, baik organisasi bisnis maupun nirlaba, pemanufaktur maupun penyedia jasa, dan organisasi lokal, regional, maupun global (Situmorang 2007). Dengan demikian merek tidak hanya sekedar identitas suatu produk ataupun hanya sebagai pembeda dari produk pesaing, melainkan merek memiliki ikatan emosional istimewa yang tercipta antara konsumen dengan produsen. Pesaing bisa saja menawarkan produk yang mirip, tetapi mereka tidak mungkin menawarkan janji emosional yang sama (Sidik 2018).

Produk yang telah memiliki brand yang kuat akan sulit untuk ditiru. Hal ini dikarenakan persepsi konsumen atas nilai suatu merek tertentu tidak mudah untuk diciptakan (Sipayung and Bobby Syahreza 2021). Dengan brand equity yang kuat, konsumen memiliki persepsi akan mendapatkan nilai tambah dari suatu produk yang tidak akan didapatkan dari produk-produk lainnya (Eka Saputri and Ratna Pranata 2014).

Pola konsumsi masyarakat kini telah banyak dipengaruhi oleh perubahan gaya hidup, seperti minum-minuman cepat saji yang lebih digemari karena praktis, harga terjangkau, cukup menghemat waktu dan memudahkan penggunanya (langsung dibuang). Salah satunya adalah air minum dalam kemasan (AMDK). Produk ini menjadi pilihan sebagai pengganti air minum putih biasa (Saptono 2012).

PT AQUA Golden Mississippi, Tbk merupakan salah satu dari sekian banyak merek yang memproduksi air mineral dengan berbagai kemasan yang dibutuhkan. AQUA sebagai market leader dikategori produk air minum dalam kemasan, telah memiliki brand equity yang kuat. Selain itu, AQUA meningkatkan perceived quality dimata konsumen dengan menambah varian pilihan air minum dalam kemasan dengan berbagai ukuran (Suprapto 2015).

\section{METODE}

Penelitian ini merupakan jenis penelitian survei metode penelitian survei digunakan untuk memperoleh atau mengumpulkan data informasi tentang poplasi yang besar dengan menggunakan sampel yang relatif lebih kecil (Fatma Yuniarti n.d.). Teknik pengambilan sampel dalam penelitian ini yaitu menggunakan metode convinience sampling dengan pengambilan data dilakukan dengan metode survei dengan menggunakan kuesioner melalui Google Formulir yang disebar melalui akun media sosial Instagram yang dimilik oleh peneliti (Amel 2020). Waktu yang digunakan untuk menyebar kuesioner sampai dengan kuesioner terkumpul kurang lebih 5 hari yaitu mulai tanggal 15 Juni 2021 sampai 20 Juni 2021.

\section{HASIL DAN PEMBAHASAN}

Berdasarkan hasil analisis penelitian yang dilakukan terhadap pengguna media sosial Instagram milik peneliti, peneliti dapat melakukan pembahasan sebagai berikut:

1. Pembahasan Hasil Analisis Persentase

Dari analisis persentase mengenai profil responden, terdapat dua karakteristik yaitu karakteristik jenis kelamin dan usia. Jawaban yang diperoleh melalui kuesioner yang disebarkan dapat diketahui bahwa:

a. Konsumen AQUA sebagian besar adalah perempuan dengan jumlah sebanyak sekitar $97,6 \%$ atau sebanyak 365 orang dan laki-laki sekitar 2,4\% atau sebanyak 9 orang. Dapat dilihat dalam gambar 1 hal ini dikarenakan kebetulan responden yang mendominasi adalah perempuan. 
Gambar 1. Persentase Jenis Kelamin Responden Jenis Kelamin

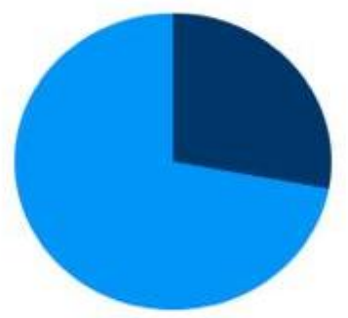

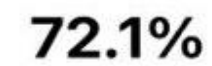

- Perempuan
$27.9 \%$

- Laki-laki

b. Konsumen AQUA yang berusia dibawah 18 tahun sekitar 59,39\% atau sebanyak 222 orang. Diikuti responden dengan rentang usia 18-30 tahun sekitar 40,64\% atau sebanyak 152 orang. Hal ini dikarenakan kebetulan responden yang merupakan pengikut dari akun peneliti mempunyai rentang usia pada gambar 2 berikut:

\section{Gambar 2. Persentase Rentang Usia Responden}

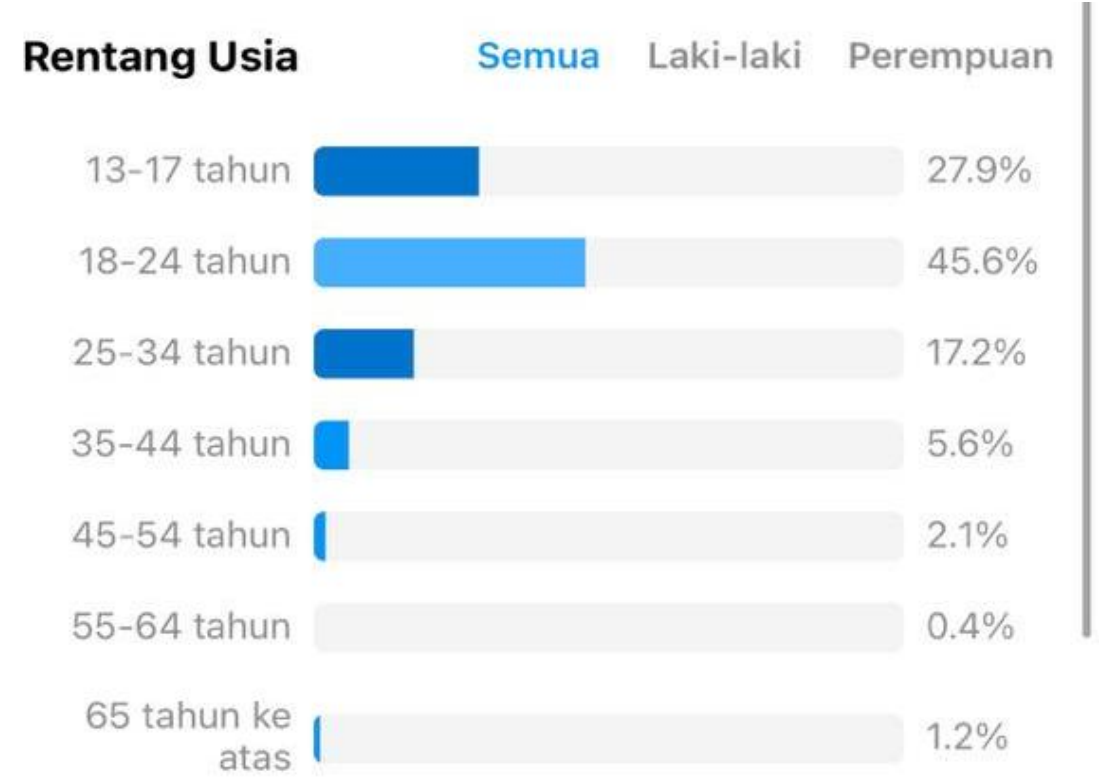

Kuesioner yang diberikan oleh peneliti terdapat tanggapan responden yang nampak dari jawaban-jawaban responden. Skala yang digunakan pada kuesioner penelitian menggunakan 5 skala interval dari 1 sampai 5 menyatakan:

$$
\begin{aligned}
& \mathrm{SS}=\text { Sangat Setuju } \\
& \mathrm{S} \quad=\text { Setuju } \\
& \mathrm{RR}=\text { Ragu-ragu } \\
& \mathrm{TS}=\text { Tidak Setuju } \\
& \mathrm{STS}=\text { Sangat Tidak Setuju }
\end{aligned}
$$


Berikut adalah tanggapan responden terhadap persepsi kualitas merek AQUA berdasarkan kuesioner yang telah disebar:

a. Tanggapan Responden Mengenai Kejernihan Air dari AMDK AQUA

Peneliti telah memberikan pertanyaan berupa: Air minum dalam kemasan (AMDK) yang diproduksi AQUA merupakan air yang jernih dan dapat dilihat pada table 1 dibawah ini bahwa sekitar 53,5\% atau sebanyak 200 responden menjawab sangat setuju, sekitar 44,4\% atau sebanyak 166 responden menjawab setuju, sekitar 1,9\% atau sebanyak 7 responden menjawab ragu-ragu, sekitar $0,2 \%$ atau sebanyak 1 orang responden menjawab tidak setuju, dan $0 \%$ untuk 0 responden menjawab sangat tidak setuju bahwa air yang diproduksi AQUA merupakan air yang jernih. Dapat disimpulkan bahwa responden sangat setuju dan percaya oleh bahwa AMDK yang diproduksi merek AQUA memiliki air yang jernih dimata konsumen.

Tabel 1. Persentase Tanggapan Responden Bersadarkan Kejernihan dari AMDK AQUA

\begin{tabular}{|r|l|r|r|}
\hline No. & $\begin{array}{r}\text { Kejernihan } \\
\text { AMDK } \\
\text { AQUA }\end{array}$ & Jumlah & $\begin{array}{r}\text { Persentase } \\
(\%)\end{array}$ \\
\hline 1. & Sangat Setuju & 200 & $53,5 \%$ \\
\hline 2. & Setuju & 166 & $44,4 \%$ \\
\hline 3. & Ragu-ragu & 7 & $1,9 \%$ \\
\hline 4. & Tidak Setuju & 1 & $0,2 \%$ \\
\hline 5. & Sangat Tidak & 0 & $0 \%$ \\
\hline & Setuju & 374 & $100 \%$ \\
\hline
\end{tabular}

b. Tanggapan Responden Mengenai Aroma dari AMDK AQUA

Peneliti telah memberikan pertanyaan berupa: Air minum dalam kemasan (AMDK) yang diproduksi oleh merek Aqua tidak berbau dan dapat dilihat pada tabel 2 dibawah ini bahwa sekitar 46,2\% atau sebanyak 173 responden menjawab sangat setuju, sekitar 47,1\% atau sebanyak 176 responden menjawab setuju, sekitar 4,3\% atau sebanyak 16 responden menjawab ragu-ragu, sekitar 1,9\% atau sebanyak 7 responden menjawab tidak setuju dan 0,5\% untuk 2 responden menjawab sangat tidak setuju. Dapat disimpulkan dari infrormasi yang didapat bahwa responden sangat setuju dan setuju bahwa AMDK yang diproduksi merek AQUA tidak memiliki aroma atau bau dimata konsumen. 
Tabel 2. Persentase Tanggapan Responden Bersadarkan Aroma dari AMDK AQUA

\begin{tabular}{|r|l|r|r|}
\hline No. & $\begin{array}{r}\text { Aroma AMDK } \\
\text { AQUA }\end{array}$ & Jumlah & $\begin{array}{r}\text { Persentase } \\
(\%)\end{array}$ \\
\hline 1. & Sangat Setuju & 173 & $46,2 \%$ \\
\hline 2. & Setuju & 176 & $47,1 \%$ \\
\hline 3. & Ragu-ragu & 16 & $4,3 \%$ \\
\hline 4. & Tidak Setuju & 7 & $1,9 \%$ \\
\hline 5. & Sangat Tidak & 2 & $0,5 \%$ \\
\hline & Setuju & 374 & $100 \%$ \\
\hline
\end{tabular}

c. Tanggapan Responden Mengenai Rasa dari AMDK AQUA

Peneliti telah memberikan pertanyaan berupa: Air minum dalam kemasan (AMDK) yang diproduksi oleh merek Aqua memiliki rasa. Dan dapat dilihat pada tabel 3 dibawah ini bahwa sekitar $14 \%$ atau sebanyak 52 responden menjawab sangat setuju, sekitar $34,2 \%$ atau sebanyak 128 responden menjawab setuju, sekitar 21,4\% atau sebanyak 80 responden menjawab ragu-ragu, sekitar $26,7 \%$ atau sebanyak 100 responden menjawab tidak setuju dan 3,7\% untuk 14 responden menjawab sangat tidak setuju. Dapat disimpulkan dari infrormasi yang didapat bahwa responden setuju bahwa AMDK yang diproduksi merek AQUA memiliki rasa dimata konsumen. Yang dimaksud rasa disini adalah rasa pahit atau rasa air asin dari produk AMDK merek AQUA.

Tabel 3. Persentase Tanggapan Responden Bersadarkan Rasa dari AMDK AQUA

\begin{tabular}{|c|l|c|c|}
\hline No. & $\begin{array}{r}\text { Rasa AMDK } \\
\text { AQUA }\end{array}$ & Jumlah & $\begin{array}{r}\text { Persentase } \\
(\%)\end{array}$ \\
\hline 1. & Sangat Setuju & 52 & $14 \%$ \\
\hline 2. & Setuju & 128 & $34,2 \%$ \\
\hline 3. & Ragu-ragu & 80 & $21,4 \%$ \\
\hline 4. & Tidak Setuju & 100 & $26,7 \%$ \\
\hline 5. & Sangat Tidak & 14 & $3,7 \%$ \\
\hline & Setuju & 374 & $100 \%$ \\
\hline
\end{tabular}

d. Tanggapan Responden Mengenai Keamanan dari AMDK AQUA 
Peneliti telah memberikan pertanyaan berupa: Air minum dalam kemasan (AMDK) yang diproduksi oleh merek Aqua tidak terkontaminasi zat lain. Dan dapat dilihat pada tabel 4 dibawah ini bahwa sekitar 28,1\% atau sebanyak 105 responden menjawab sangat setuju, sekitar 40,1\% atau sebanyak 150 responden menjawab setuju, sekitar 27,5\% atau sebanyak 103 responden menjawab ragu-ragu, sekitar 3,7\% atau sebanyak 14 responden menjawab tidak setuju dan $0,5 \%$ untuk 2 responden menjawab sangat tidak setuju. Dapat disimpulkan dari infrormasi yang didapat bahwa responden setuju bahwa AMDK yang diproduksi merek AQUA tidak terkontaminasi zat lain atau aman dimata konsumen.

Tabel 4. Persentase Tanggapan Responden Bersadarkan Keamanan dari AMDK AQUA

\begin{tabular}{|c|l|c|c|}
\hline No. & $\begin{array}{c}\text { Keamanan AMDK } \\
\text { AQUA }\end{array}$ & Jumlah & $\begin{array}{c}\text { Persentase } \\
(\%)\end{array}$ \\
\hline 1. & Sangat Setuju & 105 & $28,1 \%$ \\
\hline 2. & Setuju & 150 & $40,1 \%$ \\
\hline 3. & Ragu-ragu & 103 & $27,5 \%$ \\
\hline 4. & Tidak Setuju & 14 & $3,7 \%$ \\
\hline 5. & Sangat Tidak Setuju & 2 & $0,5 \%$ \\
\hline & Total & 374 & $100 \%$ \\
\hline
\end{tabular}

e. Tanggapan Responden Mengenai Kehigienisan Produk AMDK AQUA

Peneliti telah memberikan pertanyaan berupa: Air minum dalam kemasan (AMDK) yang diproduksi oleh merek Aqua merupakan produk yang higienis. Dan dapat dilihat pada tabel 5 dibawah ini bahwa sekitar 47,9\% atau sebanyak 179 responden menjawab sangat setuju, sekitar 42,8\% atau sebanyak 160 responden menjawab setuju, sekitar $8 \%$ atau sebanyak 8 responden menjawab ragu-ragu, sekitar $1,1 \%$ atau sebanyak 4 responden menjawab tidak setuju dan 0,2\% untuk 1 responden menjawab sangat tidak setuju. Dapat disimpulkan dari infrormasi yang didapat bahwa responden sangat setuju bahwa AMDK yang diproduksi merek AQUA merupakan produk yang higienis dimata konsumen.

Tabel 5. Persentase Tanggapan Responden Bersadarkan Kehigienisan dari AMDK AQUA

\begin{tabular}{|c|l|r|r|}
\hline No. & $\begin{array}{c}\text { Kehigienisan AMDK } \\
\text { AQUA }\end{array}$ & Jumlah & $\begin{array}{c}\text { Persentase } \\
(\%)\end{array}$ \\
\hline 1. & Sangat Setuju & 179 & $47,9 \%$ \\
\hline 2. & Setuju & 160 & $42,8 \%$ \\
\hline
\end{tabular}




\begin{tabular}{|c|l|c|c|}
\hline 3. & Ragu-ragu & 30 & $8 \%$ \\
\hline 4. & Tidak Setuju & 4 & $1,1 \%$ \\
\hline 5. & Sangat Tidak Setuju & 1 & $0,2 \%$ \\
\hline \multicolumn{2}{r|}{ Total } & 374 & $100 \%$ \\
\hline
\end{tabular}

f. Tanggapan Responden Mengenai Kemudahan dalam Mengonsumsi AMDK AQUA Peneliti telah memberikan pertanyaan berupa: Berbagai jenis kemasan dari air minum dalam kemasan (AMDK) merek Aqua memudahkan atau bersifat praktis. Dan dapat dilihat pada tabel 6 dibawah ini bahwa sekitar 52,1\% atau sebanyak 195 responden menjawab sangat setuju, sekitar 43,9\% atau sebanyak 164 responden menjawab setuju, sekitar 3,5\% atau sebanyak 13 responden menjawab ragu-ragu, sekitar $0,5 \%$ atau sebanyak 2 responden menjawab tidak setuju dan $0 \%$ untuk 0 responden menjawab sangat tidak setuju. Dapat disimpulkan dari infrormasi yang didapat bahwa responden sangat setuju bahwa AMDK yang diproduksi merek AQUA dapat memudahkan dalam mengosumsi AMDK dimata konsumen.

Tabel 6. Persentase Tanggapan Responden Bersadarkan Kemudahan dalam Mengonsumsi AMDK AQUA

\begin{tabular}{|c|l|c|c|}
\hline No. & $\begin{array}{r}\text { Kemudahan dalam } \\
\text { Mengonsumsi } \\
\text { AMDK AQUA }\end{array}$ & Jumlah & $\begin{array}{c}\text { Persentase } \\
(\%)\end{array}$ \\
\hline 1. & Sangat Setuju & 195 & $52,1 \%$ \\
\hline 2. & Setuju & 164 & $43,9 \%$ \\
\hline 3. & Ragu-ragu & 13 & $3,5 \%$ \\
\hline 4. & Tidak Setuju & 2 & $0,5 \%$ \\
\hline 5. & Sangat Tidak Setuju & 0 & $0 \%$ \\
\hline & Total & 374 & $100 \%$ \\
\hline
\end{tabular}

g. Tanggapan Responden Mengenai Logo dari AMDK AQUA

Peneliti telah memberikan pertanyaan berupa: Air minum dalam kemasan (AMDK) merek Aqua memiliki logo yang mudah dikenali dan diingat. Dan dapat dilihat pada tabel 7 dibawah ini bahwa sekitar 70,1\% atau sebanyak 262 responden menjawab sangat setuju, sekitar 26,2\% atau sebanyak 98 responden menjawab setuju, sekitar 2,7\% atau sebanyak 10 responden menjawab ragu-ragu, sekitar $0,5 \%$ atau sebanyak 2 responden menjawab tidak setuju dan $0,5 \%$ untuk 2 responden menjawab sangat tidak setuju. Dapat disimpulkan 
dari infrormasi yang didapat bahwa responden sangat setuju bahwa AMDK yang diproduksi merek AQUA memiliki logo yang mudah dikenali dan diingat dimata konsumen.

Tabel 7. Persentase Tanggapan Responden Bersadarkan Logo dari AMDK AQUA

\begin{tabular}{|c|l|c|c|}
\hline No. & Logo AMDK AQUA & Jumlah & $\begin{array}{c}\text { Persentase } \\
(\%)\end{array}$ \\
\hline 1. & Sangat Setuju & 262 & $70,1 \%$ \\
\hline 2. & Setuju & 98 & $26,2 \%$ \\
\hline 3. & Ragu-ragu & 10 & $2,7 \%$ \\
\hline 4. & Tidak Setuju & 2 & $0,5 \%$ \\
\hline 5. & Sangat Tidak Setuju & 2 & $0,5 \%$ \\
\hline & Total & 374 & $100 \%$ \\
\hline
\end{tabular}

h. Tanggapan Responden Mengenai Bentuk Kemasan dari AMDK AQUA

Peneliti telah memberikan pertanyaan berupa: Air minum dalam kemasan (AMDK) merek Aqua memiliki bentuk kemasan yang bagus. Dan dapat dilihat pada tabel 8 dibawah ini bahwa sekitar 43,3\% atau sebanyak 162 responden menjawab sangat setuju, sekitar 53\% atau sebanyak 198 responden menjawab setuju, sekitar 2,4\% atau sebanyak 9 responden menjawab ragu-ragu, sekitar 5\% atau sebanyak 5 responden menjawab tidak setuju dan $0 \%$ untuk 0 responden menjawab sangat tidak setuju. Dapat disimpulkan dari infrormasi yang didapat bahwa responden setuju bahwa AMDK yang diproduksi merek AQUA memiliki kemasan yang bagus dimata konsumen.

Tabel 8. Persentase Tanggapan Responden Bersadarkan Kemasan dari AMDK AQUA

\begin{tabular}{|c|l|c|c|}
\hline No. & $\begin{array}{c}\text { Kemasan AMDK } \\
\text { AQUA }\end{array}$ & Jumlah & $\begin{array}{c}\text { Persentase } \\
(\%)\end{array}$ \\
\hline 1. & Sangat Setuju & 162 & $43,3 \%$ \\
\hline 2. & Setuju & 198 & $53 \%$ \\
\hline 3. & Ragu-ragu & 9 & $2,4 \%$ \\
\hline 4. & Tidak Setuju & 5 & $1,3 \%$ \\
\hline 5. & Sangat Tidak Setuju & 0 & $0 \%$ \\
\hline & Total & 374 & $100 \%$ \\
\hline
\end{tabular}

i. Tanggapan Responden Mengenai Kualitas Air dari AMDK AQUA

Peneliti telah memberikan pertanyaan berupa: Kualitas air dari air minum dalam kemasan 
(AMDK) merek Aqua dari waktu ke waktu tidak berubah. Dan dapat dilihat pada tabel 9 dibawah ini bahwa sekitar $37 \%$ atau sebanyak 137 responden menjawab sangat setuju, sekitar $42 \%$ atau sebanyak 158 responden menjawab setuju, sekitar 15,2\% atau sebanyak 57 responden menjawab ragu-ragu, sekitar 5,3\% atau sebanyak 20 responden menjawab tidak setuju dan $0,5 \%$ untuk 2 responden menjawab sangat tidak setuju. Dapat disimpulkan dari infrormasi yang didapat bahwa responden setuju bahwa AMDK yang diproduksi merek AQUA memiliki kualitas yang sama dari waktu ke waktu dimata konsumen.

Tabel 9. Persentase Tanggapan Responden Bersadarkan Kualitas dari AMDK AQUA

\begin{tabular}{|c|l|c|c|}
\hline No. & Kualitas AMDK AQUA & Jumlah & $\begin{array}{c}\text { Persentase } \\
(\%)\end{array}$ \\
\hline 1. & Sangat Setuju & 137 & $37 \%$ \\
\hline 2. & Setuju & 158 & $42 \%$ \\
\hline 3. & Ragu-ragu & 57 & $15,2 \%$ \\
\hline 4. & Tidak Setuju & 20 & $5,3 \%$ \\
\hline 5. & Sangat Tidak Setuju & 2 & $0,5 \%$ \\
\hline & Total & 374 & $100 \%$ \\
\hline
\end{tabular}

j. Tanggapan Responden Mengenai Kesesuaian Ukuran Volume dan Harga dari AMDK AQUA

Peneliti telah memberikan pertanyaan berupa: Harga dari air minum dalam kemasan (AMDK) merek Aqua sesuai dengan berbagai volume yang tersedia. Dan dapat dilihat pada tabel 10 dibawah ini bahwa sekitar 47,9\% atau sebanyak 179 responden menjawab sangat setuju, sekitar 41,4\% atau sebanyak 155 responden menjawab setuju, sekitar 8,3\% atau sebanyak 31 responden menjawab ragu-ragu, sekitar 2,4\% atau sebanyak 9 responden menjawab tidak setuju dan $0 \%$ untuk 0 responden menjawab sangat tidak setuju. Dapat disimpulkan dari infrormasi yang didapat bahwa responden sangat setuju bahwa AMDK yang diproduksi merek AQUA memiliki harga yang sesuai dengan volume/ukuran dimata konsumen.

Tabel 10. Persentase Tanggapan Responden Bersadarkan Kesesuaian Ukuran Volume dan Harga AQUA

\begin{tabular}{|r|r|r|r|}
\hline No. & $\begin{array}{c}\text { Kesesuaian Ukuran } \\
\text { Volume dan Harga } \\
\text { AMDK AQUA }\end{array}$ & Jumlah & $\begin{array}{c}\text { Persentase } \\
(\%)\end{array}$ \\
\hline 1. & Sangat Setuju & 179 & $47,9 \%$ \\
\hline
\end{tabular}




\begin{tabular}{|c|l|c|c|}
\hline 2. & Setuju & 155 & $41,4 \%$ \\
\hline 3. & Ragu-ragu & 31 & $8,3 \%$ \\
\hline 4. & Tidak Setuju & 9 & $2,4 \%$ \\
\hline 5. & Sangat Tidak Setuju & 0 & $0 \%$ \\
\hline \multicolumn{2}{r|}{ Total } & 374 & $100 \%$ \\
\hline
\end{tabular}

\section{SIMPULAN}

Setelah dilakukan analisis data, berdasarkan data yang diperoleh peneliti mengambil sampel pengguna media sosial Instagram yaitu sebanyak 374 eksampler. Dengan analisis data persentase dapat diketahui gambaran konsumen AQUA sebagai berikut: Konsumen AQUA sebagian besar adalah perempuan dengan jumlah sebanyak 365 orang dan laki-laki sebanyak 9 orang. Konsumen AQUA yang berusia dibawah 18 tahun sebanyak 222 orang. Diikuti responden dengan rentang usia 18-30 tahun sebanyak 152 orang. Sebesar 97,9\% responden percaya dengan kualitas yang diberikan bahwa AMDK yang diproduksi merek AQUA memiliki air yang jernih dimata konsumen. Sebesar 93,3\% responden menyatakan bahwa AMDK yang diproduksi merek AQUA tidak memiliki aroma atau bau dimata konsumen. Hal tersebut menunjukan bahwa kualitas dari AMDK AQUA sangat bagus. Sebesar 48,2\% responden setuju bahwa AMDK yang diproduksi merek AQUA memiliki rasa. Yang dimaksud rasa disini adalah rasa pahit atau rasa air asin dari produk AMDK merek AQUA. Sebanyak 21,4\% responden ragu apakah air AQUA mempunyai rasa dan sebanyak 30,4\% responden menjawab tidak setuju dan sangat tidak setuju bawa AMDK yang diproduksi merek AQUA memiliki rasa. Dengan persentase tersebut menyatakan bahwa persepsi konsumen terhadap rasa dari AMDK AQUA berbeda-beda. Sebesar 68,2\% responden menyatakan setuju bahwa AMDK yang diproduksi merek AQUA tidak terkontaminasi zat lain atau aman dimata konsumen. Namun sebanyak 27,5\% responden masih ragu akan keamanan AMDK merek AQUA ini. Sebesar 90,7\% responden sangat setuju bahwa AMDK yang diproduksi merek AQUA dipercaya merupakan produk yang higienis dimata konsumen. Sebesar 96\% responden setuju bahwa AMDK yang diproduksi merek AQUA dapat memudahkan dalam mengosumsi AMDK dimata konsumen. Sebesar 96,3\% responden setuju bahwa AMDK yang diproduksi merek AQUA memiliki logo yang mudah dikenali dan diingat dimata konsumen. Sebesar 96,3\% responden setuju bahwa AMDK yang diproduksi merek AQUA memiliki kemasan yang bagus dimata konsumen. Sebesar $79 \%$ responden setuju bahwa AMDK yang diproduksi merek AQUA memiliki kualitas yang sama dari waktu ke waktu dimata konsumen. Namun sebesar $21 \%$ sisa responden masih ragu dan tidak setuju akan konsistensi kualitas dari AMDK AQUA. Sebesar 89,3\% responden setuju bahwa AMDK yang diproduksi 
merek AQUA memiliki harga yang sesuai dengan volume/ukuran dimata konsumen.

\section{BIBLIOGRAFI}

AQUA. Danone-AQUA. Diambil dari : www.aqua.com (Diakses tanggal 28 Mei 2021).

Amel, Amalia Fajrin. 2020. "Pengaruh Promosi Penjualan Dan E-Service Quality Terhadap Keputusan Penggunaan Aplikasi Ovo.” JRMSI - Jurnal Riset Manajemen Sains Indonesia 11(2): 201-23.

Marheni Eka Saputri, and Tutut Ratna Pranata. 2014. "Pengaruh Brand Image Terhadap Kesetiaan Pengguna Smartphone Iphone.” Jurnal Sosioteknologi 13(3): 193-201.

Fatma Yuniarti, Sutarno. "MENGADAKAN PROGRAM RUMAH BELAJAR BIMBINGAN BELAJAR BAHASA INGGRIS 'ENGLISH IS NOT EXPENSIVE' DI DESA PODOREJO SEBAGAI CARA UNTUK MENINGKATKAN KEMAMPUAN ANAK- ANAK DAN REMAJA DALAM MEMAHAMI BAHASA INGGRIS.” : 22-26.

Saptono, Setyo Budi. 2012. "Pola Konsumsi Masyarakat Perkotaan: Studi Deskriptif Pemanfaatan Foodcourt Oleh Keluarga.” Jurnal Biokultur Vol.I/No.2: 157-178.

Sidik, Abdurrahman. 2018. “Analisis Iklan Produk Shampoo Pantene Menggunakan Teori Semiotika Pierce.” Technologia: Jurnal Ilmiah 9(4): 201.

Sipayung, Tuahman, and Bobby Syahreza. 2021. “Analisis Persepsi Konsumen Tentang Atribut

Produk Serta Pengaruhnya Terhadap Keputusan Pembelian Smartphone Oppo (Studi Kasus Pada Toko Tia Ponsel Di Kota Pematangsiantar).” Manajemen : Jurnal Ekonomi 3(1): 11-24. Situmorang, Syafrizal Helmi. 2007. Studi Kelayakan Bisnis Buku 1.

Sudarwati, Yuni, and Venti Eka Satya. 2013. "Strategi Pengembangan Merek Usaha Mikro, Kecil, Dan Menengah.” Jurnal Ekonomi \& Kebijakan Publik 4(1): 89-101.

Suprapto, Haddy. 2015. “Analisis Sikap Konsumen Terhadap Atribut Produk Air Minum Aqua

Dalam Kemasan Di Kota Yogyakarta Dengan Pendekatan Model Sikap Multiatribut Fishbein.” 13(2): 235-42. 